\title{
The Informal Sector and Mortgage Financing in Ghana
}

\author{
I.Decardi-Nelson, O. R. Asamoah, B. Solomon-Ayeh and K.A. Nduro \\ Building and Road Research Institute \\ Council for Scientific and Industrial Research \\ Kumasi, Ghana \\ DOI:http://dx.doi.org/10.4314/gjds.vgi2.8
}

\begin{abstract}
The increasing cost of building materials coupled with other challenges hinder the ability and desire of people to own houses. Over the years, accessibility to mortgage financing has become more skewed towards the formal sector to the neglect of the informal sector based on perceived and real challenges with informal sector financing. These notwithstanding, the need for innovative mortgages for the informal sector cannot be overemphasised as more than $60 \%$ of employees within that sector cannot afford to own a decent accommodation. The Case Study Approach was employed to gather data from about 30\% of construction artisans in Ashanti Region. The study revealed that 6 out of the 8 basic eligibility criteria were exclusion factors to the informal sector. These were the proof of address, proof of employment and income, ability to service the loans, the loan duration and the deposit. The paper recommends that there should be a financing mechanism that is flexible in terms of repayment. There should also be short term repetitive loans with some increment prior to first payment completion and flexible collateral that the borrower can afford. Finally, mortgage loans can be in the form of building materials
\end{abstract}

KEYWORDS: Informal Sector, Mortgage Financing, Accessibility, and Eligibility Criteria

\section{Introduction}

Ghana is experiencing high rates of urbanization, resulting in the increase of unplanned settlements especially in the urban and the peri-urban areas. These unplanned settlements provide homes for both the poor and the middle-class, as affordable housing is simply non-existent. Studies into the development of housing in Africa suggest that the high income earners have enough resources to own houses while the middle class finance the construction of their own houses incrementally, often in unplanned and unapproved areas which lack certain basic amenities such as water, electricity and access roads (Trust, 1995). The middle income earners are mostly the public and civil servants who have 
government guarantees for quasi-mortgage available to high-net worth clients through a number of banks.

Over the years there have been efforts to introduce mortgage financing in Ghana. This initiative was started by the Home Finance Company (HFC) and now, traditional commercial banks have come on board. The mortgage system, however, has its challenges. For instance, until secure land title systems are put in place, banks are unable to provide collateralised mortgage finance. Also, increasing interest rates, unstable inflationary trends, limited long term financing options and an economy dominated by the informal sector (6o\% of the labour force) are some of the challenges facing financial institutions engaged in mortgage financing (Tomlinson, 2007). Mortgage institutions are faced with limited access to capital due to limited mortgage infrastructure, credit bureaus and secondary market. With majority of the labour force employed in the informal sector, it presupposes that any policy intervention may be a failure once the informal sector is excluded. A study by Ansah (2002) has shown that less than 30\% of households in Ghana can afford a mortgage because of high prices, high real interest rates and unavailability of long-term funding. Costly formal-sector systems for property rights, land use development, property transfer taxes, contribute to limit the demand for mortgage money and instability of household income makes long-term debt risky to lenders and unattractive for many families.

Notwithstanding these pitfalls, there are some identifiable positives, which would make house ownership flexible and easy to access and also provide the opportunity for everyone to own a house. The argument for this study is that mortgages are enjoyed basically by formal sector employees who are in the minority while operators and employees in the informal sector who form the majority of the labour force are excluded. Hence, the aim of this paper is to describe the mortgage system with a view to explaining how best the urban informal sector in Ghana can be incorporated. The following specific objectives were addressed in this paper to assess the criteria used by financial institutions in mortgage loan and identify the factors that impedes the access to mortgage financing by households in the informal sector.

\section{Background Literature}

\section{The Informal Sector and Housing Finance in Ghana}

An analysis of housing conditions reveals that in Ghana, $48.9 \%$ of the households live in accommodation associated with the compound. Another $25.3 \%$ live in detached houses and $15.3 \%$ reside in semi-detached houses (Afram, 2009). Economic performance has improved in recent years with growth rate reaching 6.4\% in December, 2007 (GSS, 2008). While inflation had remained slightly stable keeping interest rates also slightly firm, the housing finance market has not seen much development due to the inability of the urban 
poor to acquire their own houses. Home Finance Company now renamed HFC bank, was the pioneering company to begin housing finance in Ghana in the 1980 .

Real estate companies such as Regimanuel Gray, Manet Cottage and Ayensu Real Estates Limited have constructed houses for sale with prices starting from $\$ 35,000$ upwards. This situation calls for serious mortgage financing since this would assist people to acquire their own houses. The involvement of some financial institutions such as United Bank for Africa (UBA), Barclays Bank and Ghana Home Loans indicates that the housing deficit in the country as of 2010, estimated to be between $800,000-1,000,000$, could be reduced. Furthermore, in August 2007, the International Finance Corporation invested \$25 million to support three financial institutions -Ecobank Ghana, Merchant Bank and Fidelity Bank, to boost their mortgage operations in Ghana. According to studies conducted by the Ghana Real Estates Developers Association (GREDA, 2000) 500,000 houses are needed annually.

Between 1990 and 1998, the Social Security and National Insurance Trust (SSNIT) provided over 30,000 blocks of flats in the country, principally in regional capitals like Accra, Kumasi Cape Coast and Takoradi but development by SSNIT stopped until the Ghana Government stepped in with an affordable housing programme. The construction of these government affordable housing units is taking place at Borteyman and Kpone in Greater Accra and Asokore Mampong in the Ashanti Region. The same is being replicated in other regions such as the Eastern region. Accra, currently with a population of approximately 4 million, is estimated to grow at approximately $4 \%$ per annum making housing an important aspect of the national development. The adoption of a market-oriented mortgage system will help improve the lives of many Ghanaian families that live in substandard housing conditions.

\section{Mortgage Financing in Ghana}

A mortgage is a form of a debt, which is secured by the real estate property submitted by the borrower to the lender (Asare \& Whitehead, 2006). A mortgage is also a legal document wherein the owner pledges the title of his property in the form of security to a creditor in exchange of financial aid. The mortgage depends on many parameters which mainly include risk enduring capacity, personal financial goals and capabilities and income (Merrill \& Tomlinson, 2006).

Mortgage financing is vital to every economy because it accounts for a sizeable portion of a country's productive activity through backward linkages to land and labour markets, as well as related industries. Since it is inextricably linked to a country's economic development in the areas of strengthening financial institutions, promoting social stability and improving people's lives, the sector should have by now seen enormous growth, culminating in affordable houses for Ghanaians. At the individual level, mortgage is the pledging of a property to a lender as a security for a mortgage loan and this not 
only enables access to home ownership but also to meet basic needs as means of economic empowerment. In Ghana, only the rich or a few people have access to it.

\section{Advantages of Mortgages}

Mortgages serve as a source of investment for many investors particularly those with long-term liabilities such as Pension Funds and Insurance Companies. Thus, it is an important area of investment. Its advantages include the following:

- In mortgage financing, the applicant is allowed to hold on to the ownership of a property while at the same time use it as a collateral to obtain funds. Here, the principle of joint ownership is used until the loan repayment is completed. However, the financial institution does not receive any share in the ownership of the property but is only entitled to take back the principal amount and the interest accumulated on the principal amount lent. The availability of money is not a prerequisite. In a mortgage, the lender can only claim ownership on a property in case of default on the repayment schedule (Buckley and Kalarickal, 2005).

- The interest payments on the mortgage are tax free in nature.

- Since the schedules of repayment are pre-determined, it allows one to plan future financial expenses accordingly.

- By availing a mortgage one has access to cash flow.

- Creation of long term, high quality mortgage lending operations in Ghana.

- Availability of long term, local currency funding.

- Provision of bankable and affordable housing.

- Increased market competition resulting in greater efficiency and improved pricing of mortgage products.

- Increased economic activity through availability of down-stream opportunities (Decardi-Nelson and Solomon-Ayeh, 2011).

\section{Disadvantages of Mortgages}

The disadvantages of mortgages to the borrower include the following:

- The need of depositing collateral as security works out to be the biggest drawback of mortgages. It restricts the kind of people who can secure a mortgage as only home owners or other asset owners can do so.

- In case of default on the payment, the lender has the right to claim the property deposited as collateral and then subsequently sell it off to claim back the loaned amount. One has to ensure while taking the mortgage that there is a clause 
mentioned that on repayment of the mortgage the lender has to release the ownership title (Decardi-Nelson and Solomon-Ayeh, 2011).

- The lender as per convenience can define several events which it might term as a default and this generally includes inability to pay back the loan, bankruptcy, insolvency or any breach in the mortgage agreement. Therefore the risk of one ending up losing property increases substantially (Basu, et al, 2004).

\section{Categories of Home Mortgage}

Among the most popular home financing options in Ghana is the traditional Fixed Rate Mortgage (FRM). This is the loan of choice in nearly $70 \%$ of home purchase transactions. The characteristic of FRM that makes it most appealing to many consumers is its stability (Ansah, 2002). The interest rate of this loan is fixed at the beginning and remains the same throughout the term of the loan, regardless of changes in the prevailing market rate. This allows the consumer to rely upon a stable monthly payment on the principal and interest throughout the term of the loan, whether it spans 15 years or 30 years.

Adjustable Rate Mortgage (ARM) is another option that has become popular in real estate transactions. These loans have an interest rate that is tied to an index, changing with prevailing market rates. Certain intervals at which the interest rates are adjusted are specified in the loan contract. If the prevailing market rate has increased from one adjustment period to the next, the monthly loan payments will rise. If interest rates have fallen, so too will the consumer's payment. Often, there are caps placed on the amount that the rate can change during each adjustment period, and some carry a lifetime cap, limiting the amount rates can be increased over the term of the loan. Under the umbrella of the two main categories of home loans, fixed rate and adjustable, are a number of variations, some of them combining characteristics of both (Ferguson, 2003). These are the Government Guaranteed Mortgage Loans, Option ARMs, Balloon Mortgages, Biweekly Mortgages, Bimonthly Mortgages and Commercial Mortgage Finance.

\section{Challenges of Mortgage Financing in Ghana}

For many years, the provision of housing in Ghana has largely been based on informal financing. Several efforts in the past (establishment of the First Ghana Building Society (FGBS), the defunct Bank for Housing and Construction (BHC) and the former Social Security Bank) to institutionalize a mortgage industry were hampered by macroeconomic instability and the absence of long-term financing opportunities. However, the current improved macroeconomic environment has limited the major risk factors such as high inflation rates, high interest rates and volatile exchange rates in mortgage financing (Decardi-Nelson and Solomon-Ayeh, 2009).

Presently, the main underlying factor affecting the development of a mortgage industry in Ghana is lack of secure and transparent titled lands, with the consequential reduction in the granting of mortgage loans (Grant, 2005). The backlog of land title applications 
perpetuates multiple sale of land, thus, the land market cannot operate effectively to either enable the development of a formal market for mortgage or to act as security for mortgage finance. Mortgage patronage is also affected by a weak regulatory housing framework. Studies (Groves, 2004; Grant, 2005) have shown that most housing and landed properties in Ghana are not properly registered. The condition of properties owned fit the description by d'Cruz, and Satterthwaite (2004) that many possessions are poorly documented and cannot be readily turned into capital, used as collateral or traded outside the domestic market, thereby disqualifying many potential mortgagors from the market. On the demand side, high mortgage payment to income ratio and quotation of mortgages in foreign currency has often discouraged potential mortgagors, especially since mortgagors are required to repay debts (borrowed in foreign currency) in local currencies. In many instances, therefore, high inflation and volatile exchange rate movements have tended to price out borrowers (Decardi-Nelson and Solomon-Ayeh, 2011).

In general, Ghanaians have not been active participants in the mortgage financing market due to high commission fees, issues of risk, affordability and lastly high prices of houses offered by real estate developers. The challenge therefore is to develop a mortgage market that addresses some of these issues and to remove the perception that the average Ghanaian is apprehensive about the use of loans to construct a house.

\section{The Informal Sector}

The concept of the informal sector has been debated since the early 1970s. However, it has continued to be used by policy makers, labour advocates and researchers because of the reality it seeks to capture which is the large share of the global workforce that remains outside the world of full-time, stable, and protected employment. Currently, there is renewed interest in informal arrangements, and this stems from the fact that informal arrangements, have not only persisted and expanded, but have also emerged in new guises and in unexpected places (ILO, 2002).

Several types of definitions have been given to the term 'informal sector' which may be linked to specific views or identifiable schools of thought (Charmes, 1990). The best known of these definitions is that formulated by the ILO report on Kenya (Haan, 1989) which includes seven criteria for the informal sector; namely' Ease of entry, Reliance on indigenous resources, Family ownership of enterprises, Small-scale operation, Labourintensive and adapted technology, skills acquired outside the formal schooling system and, Unregulated and competitive markets.

Sethuraman (1976) postulates a number of 'suggestive criteria' for identifying the urban informal sector and that an enterprise should be regarded as 'informal' if at least it has one of the following conditions:

- It employs up 10 persons;

- It operates on an illegal basis contrary to government regulations; 
- Members belonging to the household of the head of the enterprise participate in the activity of the enterprise;

- It does not observe fixed hours/days of operation;

- It operates in a semi-permanent or temporary structure or in a variable location;

- It does not use electricity;

- It does not depend on formal financial institutions for its credit needs;

- The enterprises output is not distributed through other enterprises; and

- Almost all persons associated with the enterprise have fewer than six years of schooling.

The above two definitions (ILO and Sethuraman) were formulated by developing a set of characteristics that distinguished the informal from the formal sector. These are the main features emerging from more than two decades of informal sector surveys (Charmes, 1996) and one of the reasons the term 'informal sector' is so problematic is that it lumps into one category, a wide variety of economic activities, which offer very different potential for income earning (Lund, 1998). After decades of the existence of the concept, the informal sector is still a topic which elicits diverging views about how to define it, how to classify it, and especially how to respond to it. There is even a debate on what to call it. However, there is little divergence now that the informal sector exists and will be with us for the foreseeable future (Bangasser, 2000).

\section{Methodology}

The Case Study research approach was used for this study. The paper focused on the eligibility criteria for accessing mortgage financing and how the informal sector employees are excluded. Hence, the methodology used was to identify the basic criteria and characteristics of the informal sector based on literature. Then both the formal and the informal sectors were synchronized to bring out areas of inclusion and exclusion. The factors leading to the inability or otherwise of the informal sector households to access mortgage in Ghana were critically assessed. One important component of the informal sector namely artisans were selected as the unit of analysis for this paper. Another reason for their selection was that they play a very important role in housing provision and the construction industry in general. To this end, members of the Ashanti Region branch of the Artisans Association were sampled for interview to ascertain their general data and relate them to the eligibility criteria for accessing mortgage in Ghana. By putting the two side by side, factors that served as elimination issues were identified and explained in the analysis and discussions. In all 80 artisans out of 240 registered members of the Association were purposively sampled because they are the informal sector worker in the construction industry. Thus, the sample size was about $33 \%$ of the sample frame. Table 
1 below gives a breakdown of the sampled population by professions. About $35 \%$ of the sampled artisans were masons while $15 \%$ were plumbers (see Table 1).

Table 1: Construction Artisans Sampled for the Study

\begin{tabular}{|l|l|l|}
\hline Professions & Frequency & Percentage \\
\hline Plumbers & 12 & 15 \\
\hline Painters & 10 & 12 \\
\hline Steel benders & 5 & 6 \\
\hline Masons & 28 & 35 \\
\hline Carpenters & 15 & 20 \\
\hline Tillers & 4 & 5 \\
\hline Electricians & 6 & 7 \\
\hline Total & 80 & 100 \\
\hline
\end{tabular}

Source: Field Survey

\section{Findings and Discussions}

\section{Requirements for Mortgage and the Informal Sector}

The development of a mortgage market would improve the efficiency of the housing finance system in developing countries. It would particularly improve the affordability of borrowing households, mostly through longer amortization terms. However, the expected acceleration of mortgage markets mainly depends on the capabilities of mortgage lenders, their degree of acceptable transformation risks, and their capacity to issue long-term securities (Ziad et al, 2004).

For the past decade, various countries have gone through the process of developing viable and sound mortgage finance markets. One of the main objectives has been to improve the affordability of and access to better housing for households, while achieving gains in financial sector efficiency through introducing new financial securities to help unlock new sources of financing for the real estate sector.

Long-term mortgage finance supported by capital markets is available to upper and middle class households. For many households, the housing solutions supported by traditional mortgage finance are not appropriate. The absence of proper title to a home or proof of stable income may make some households ineligible for mortgage loans. Capital market support of housing finance in developed countries has traditionally been based 
on three pillars: Loan security against real property, Proper appraisal of that property, Rigorous documentation of borrower income and assets to support underwriting requirements.

In Ghana, borrowers who can afford to service a home purchase loan may not be eligible for a mortgage because their applications are deficient in one of these areas. They may be ineligible because they do not have title to their home or because their home may be difficult to appraise. In other situations, even with titled property, the borrower may work in the informal sector and therefore not be able to verify his or her income. In these instances, it becomes difficult to determine a suitable criterion to use to give out mortgage loans.

Increased economic activities along with burgeoning informal sector activities increase the demand for credit to finance these activities. Formal sector credit institutions are bogged down in their functions by government regulatory controls, interest rate limits, loan ceilings, collateral requirements, high administrative and procedural costs and subsidized discounts. These consequently reduce their share of the credit markets leaving a huge gap in the demand and supply of credit.

Informal Credit Markets (ICM) can be established to support people in the informal sector. With advantages of unregulated money supply, easy accessibility, easy liquidity, low "administrative" and procedural costs, little or no collateral/mortgage requirements, flexibility in interest rates and repayment schedules, this scheme could serve those in the informal sector. ICMs are ideally suited to cater to the lower income groups and informal sector's requirement of credit. In Ghana, the informal sector makes up about $70 \%$ of the labour force (Solomon-Ayeh, 2009). However, given the features and characteristics of the informal sector, access to credit and any formal sector related information is difficult. As discussed earlier, the mortgage system as pertains in Ghana is very formal and can only be obtained through the banking system. This section looks at the criteria for assessing who is eligible for a mortgage and factors within the informal sector that takes them far away from these criteria. The criteria are as follows:

\section{Age}

Prospective applicants for mortgage financing in Ghana must be at least 18 years and no more than 65 years. The maturity of the mortgage should not extend beyond the applicant's retirement age. Prospective applicants above 55 years should ensure that they can arrange 15 year life insurance coverage before applying for a mortgage. The informal sector is dominated by the youth ranging between the ages of 18 to 35 years and also, within the informal sector there is no retiring age. The age structure for the sampled artisans showed majority (35\%) were aged between 26 to 32 years with $19 \%$ being above 45 years. The oldest artisan sampled was 53 years of age and was an electrician. Table 2 indicates that $3 \%$ of the respondents ( 2 apprentices) were less than 18 years. 
Table 2: Age Distribution of Respondents

\begin{tabular}{|l|l|l|}
\hline Age Distribution & Frequency & Percentage \\
\hline Less than 18 years & 2 & 3 \\
\hline $18-25$ years & 19 & 24 \\
\hline $26-32$ years & 28 & 35 \\
\hline $33-40$ years & 15 & 19 \\
\hline $41-48$ years & 9 & 11 \\
\hline 49 years and above & 7 & 9 \\
\hline Total & 80 & 100 \\
\hline
\end{tabular}

Source: Field Survey

Therefore, mortgage providers should rather be more comfortable with informal sector workers regarding the requirement of age. Hence, age was not an "exclusion factor". However, that is not the case as other factors such as ease of entry and exit and the unstable nature of businesses within the sector tend to 'push' mortgage providers away, hence the exclusion of the informal sector workers.

\section{Proof of Identification-}

The first criterion is for the person seeking a mortgage to provide proof of identification. This is normally any nationally accepted identification such as a passport, driver's license, voter's ID card, National Health Insurance Scheme (NHIS) card. The people in the informal sector are able to pass this criterion. The commonly used proofs of identification are the NHIS and voter's cards. All sampled artisans had one or more of the proof of identity. The most common was the NHIS, which every artisan had because there was a strong campaign from their leadership. Almost $92 \%$ of the artisans had a voter's ID which was also acceptable for accessing mortgage. Table 3 below indicates that only $13 \%$ of sampled artisans had driver's licenses with $26 \%$ using their Passport as their identification. Therefore, it is fair to conclude that the eligibility criterion of proof of identification was not an "exclusion factor" to the informal sector especially the artisans in accessing mortgage in Ghana.

Table 3: Common Types of Identifications and the Proportions available

\begin{tabular}{|l|l|}
\hline Types of Identifications & Percentages \\
\hline NHIS Card & 92 \\
\hline Voter's ID & 87 \\
\hline
\end{tabular}




\begin{tabular}{|l|l|}
\hline Passport & 26 \\
\hline Driver's License & 13 \\
\hline
\end{tabular}

Source: Field Survey

\section{Proof of Address}

The borrower must have a residential and/or employer address. This are mostly derived from recent utility bills such as electricity, water and telephone bills, property rates and rental agreements. Informal workers can provide proof of address since every person pays utilities and also these days most property owners enter into rental agreements with all renters. However, mortgage providers are more comfortable when the proof of address is a company one. This, the formal workers can easily provide but not the informal worker. A study of the credit worthiness of informal enterprises in Ghana by the Private Enterprise Foundation (PEF) in 2004 stated the problem of incorrect addresses as provided by the enterprises to the financial institutions as one of the reasons for the refusal of the banks to give credit facilities to the informal enterprises. This suggests that if employees of such informal sector companies are to use the addresses of their work places to fill out the forms, they would also be rejected on the grounds of providing false information.

\section{Proof of Employment}

This is another factor that leads to the exclusion of the informal sector workers in accessing mortgage facilities. In the informal sector, employment is by word of mouth and it is through the same process that one is sacked from the job. This means that while the mortgage providers would require proof of employment in the form of an appointment letter or a letter of consent from the employers, the informal worker cannot provide any of these. There should be employer reference confirming that the borrower is currently in employment. There should also be certified statement of income for self-employed people who save. Construction workers thus construction artisans are not given appointment letters upon being employed. The survey indicated that none of the sampled artisans had ever been employed and given an appointment letter. For about $80 \%$ of the artisans, employment was by word of mouth. The remaining $20 \%$, employment was through third parties. The issue of third parties was explained as employment through friends who are contracted on a particular job and hence do not have the time and space to be part of the new construction. For about $46 \%$ of the artisans interviewed, they go round areas perceived to be "construction hub", that is, localities within the Metropolis such as periurban areas where new residential building are springing up in search of jobs. About 37\% of the sampled artisans have never been employed by the owner of the structure thus, for these artisans they get employed by other artisans who have been contracted by the owners of the various structures. 
From the above discussions, there is a clear indication that the informal sector workers in the construction industry (artisans) cannot provide any proof of employment and hence are cut off from accessing mortgage. Another fact is that, employers of these artisans would not be willing to sign any document indicating their status as employers. The main reason is that more often than not, they do not have any personal relationship with these artisans. Sometimes, the employer might not even know why the artisan is staying and where he/she can be located in the event of any mishap.

\section{Proof of Income}

The provision of proof of income is another criterion for accessing mortgage financing in Ghana that discriminates against the informal sector workers. The more acceptable proof of income is the pay slips or an undertaking signed by the head of the institution a borrower works with. However, given that informal sector operators are often selfemployed and those who are employed by others are paid cash and hence no records of how much one gets, they cannot provide any pay slips to be used for the assessment. Also, most workers in the informal sector do not keep records of their monthly income. Studies by Solomon-Ayeh (2010) and Sagoe-Addy (2008) on informal sector operators in the Kumasi Metropolis indicate that about $80 \%$ are wage earners and the remaining 20\% who are salaried workers are paid in cash and thus are excluded from the banking sector. This criterion is the basis for the exclusion of people in the informal sector from obtaining mortgage. Therefore any system that seeks to help employees in the informal sector to be able to acquire or build their own houses needs to put in strategies that would acknowledge and accept the inability of these persons to provide proof of income.

Another proof of income which is sometimes accepted is a letter from one's employers indicating that the salary would be channeled through the bank. However, studies by the Private Enterprise Foundation in 2004 has revealed that about $65 \%$ of informal sector operators are non-banked and have no administrative section or officer and therefore cannot give their workers any letter of consent. This revelation was confirmed by the survey for this paper, as about $85 \%$ of the sampled artisans were not operating a bank account. The remaining $15 \%$ though had an account but were with banks that are not into mortgage financing. Also, the study revealed that all the artisans were paid daily wages and in cash and not through any financial or banking system.

\section{Capacity/Ability to Service the Loan}

As part of the requirement for a mortgage, the applicants should be able to provide complete and accurate information regarding their financial responsibilities and commitments to enable the financial institution verify the ability of the applicant to service the loan. The applicant's monthly repayment obligation under the mortgage agreement must generally not exceed $40 \%$ of their gross income. Where the applicant has other existing loans, the combination of mortgage installment plus other loans should not exceed $60 \%$ of the gross income. Incidentally, in most cases, the proof 
of income is used as a proxy for the ability to service the loan and as already stated, informal workers do not have any proof of income in the form the financial institutions would like to see. However, Solomon-Ayeh (2010) in a study of street traders in Kumasi Metropolis and Yankson (1995) while studying the informal sector in Accra concluded that income levels within the sector is averagely higher than those within the formal sector, though irregular. Therefore, in as much as the capacity of the informal sector worker to service any loan is not in doubt, the documentation of this ability sees it as otherwise. Also, because of the irregularity of the income levels within the sector, the financial institutions are not able to easily calculate the loan payback period which is important for their financial accounts. This same factor has a bearing on the levels of interest rates the institutions can and should use. Simply put, there are insecurity issues regarding the provision of mortgage financing to the informal sector, which can only be addressed through unorthodox methods since the formal existing strategies have failed to tackle these issues. These factors where again confirmed by the study of artisans sampled for this study. For instance, there is no documentation for the daily wages paid to the artisans.

\section{Deposit}

In Ghana, prospective home-buyers are required to contribute a minimum of between $10-25 \%$ of the property value. The borrower will be required to provide evidence of this amount at the time of the mortgage application and deposit it in a designated account before the mortgage facility is disbursed. This is another criterion that discriminates against the informal sector worker. It has already being established that majority of workers within the informal sector are wage earners whose pay are given to them in cash. They have a very low savings culture and their ability to save is curtailed by the low wages they get for services rendered. Hence, making it a requirement for such a person to deposit $10-25 \%$ on a $\$ 30,000$ house clearly serves as a push factor against the accessibility of mortgage of the workers within the informal sector.

\section{Duration of the Mortgage}

The typical maximum duration of a mortgage loan in Ghana is 15 years. Many lenders allow borrowers to pre-pay their mortgages if they choose. The duration of the mortgage facility is determined by a number of factors. The most important one is the interest rate used for the calculation which in itself is a function of the level of income of the applicant. It has been earlier established that the irregular income levels within the sector makes the interest rates used by the financial institutions very high and this eliminates the informal sector operators.

From the above discussions, it is clear that six out of the eight criteria used by the financial institutions as a requirement for obtaining mortgage-funding leads to the exclusion of workers within the informal sector. Incidentally, the two that seem to be in favour of the 
sector (age and proof of identification) do not have any bearing on the amount of funding an applicant is eligible to obtain. Hence, any attempts to capture the informal sector workers in the mortgage financing area need to design strategies to circumvent the six important requirements. The pertinent issue is that financial institutions who provide mortgage facilities view the informal sector as an unstable, insecure and risky sector to deal with and would rather avoid it rather than find ways of capturing it.

\section{Conclusions}

Statistics in Ghana indicate that the low and middle-income groups constitute about $73 \%$ of the country's labour force. As earlier stated, these groups of people do not have the financial layout to build their own houses. Incidentally, there are mostly found in the informal sector. This study has shown that the informal sector households cannot fulfill most of the basic criteria for mortgage financing given the characteristics of the sector. However, given the large numbers involved, it is incumbent on the mortgage institutions to ensure that the eligibility criteria are made flexible to attract households within the informal sector. Such a move has the potential to lead to a reduction in the housing deficit.

\section{Recommendations}

For informal sector workers, there should be a financing mechanism that will be flexible and pragmatic. First, there should be a redefinition of collateral or guarantor. It should not necessarily mean the borrower should have a house to use as collateral before a mortgage will be given. Mortgage should also be in small short term repetitive loans and since the borrower does not have a fixed monthly income, he or she can be given loans in bits in the sense that if the first batch of loan is repaid completely, about 10 or 20 percent could be added and given to the borrower until the time the borrower is through with the project. Flexible repayment schedules should also be given. For the informal sector worker, there are times that economic activities will be down and other times that the economy will boom. Packages must be made for these circumstances.

Second, there should be ease of physical access and this should not be difficult which means that there should not be many complex processes to go through. If possible, at the time the borrower needs the money, he or she should not be required to make a deposit of a particular percentage of the amount to be borrowed. Housing finance loans can also be in the form of building materials because in some most cases, those in the informal sector may be tempted to invest the loan in their business instead of what was stated in the document. Giving mortgage in the form of building materials will channel the loan into the right purpose as intended.

Third, the banks would find it easier and more convenient dealing with associations or groups. It is therefore believed that once members of the informal sector join forces and form unions and associations with a clearly spelt out constitution which would govern the 
activities of the associations, they would to a large extent become attractive to the banks. In this vein, the banks would be dealing with that association as a unit rather than directly with individuals. Mortgage institutions should also collaborate with the various welfare systems of the informal sector, for example the credit unions, to enhance security and prompt payment of loans. Mortgage institutions should provide the platform to explain all relevant information to the informal sector. This will eliminate the perception that the mortgage housing system is for the elite or high-income earners in Ghana and would take cognizance of the poor and those operating in the informal sector. This would go a long way to mitigate some of the problems faced by the informal sector in securing mortgage from the financial institutions.

Finally, government policies should be formulated to favour the informal sector as well as the formal sector. In Ghana, in 2009, financial institutions were chasing both the formal and informal sectors to acquire all kinds of loans at very competitive interest rates, all due to government policies. When the government involves the informal sector, the financial institutions would see the need to educate the informal sector on the importance of doing business with them. This would help the informal sector to appreciate the need to save with the financial institutions so that at a later date their savings or accounts could be used as collateral for securing mortgages.

\section{References}

Amin, A.T.M.N. (1996). "The Informal Sector Paradigm: Analytical Contributions and Developmental Role." Regional Development Dialogue, Vol. 17, No. 1, Editorial Introduction, UNCRD Publication.

Ansah, S. B. 2002. "Contribution of Formal Housing Institutions in Housing the Low-income and the Poor: The potentials, financial constraints, options and experiences of the African Region". UN-Habitat Financing Adequate Shelter for All: Addressing the housing finance problem in developing countries. UN-Habitat, Nairobi.

Asare, E. and C. Whitehead. 2006. "Formal Mortgage Markets in Ghana: Nature and implications". RICS Research Paper Series Vol 6, No 13.

Bangasser, P. (2000). The ILO and the lnformal Sector: An Institutional History, Employment Paper, Geneva, ILO Publications, International Labour Office. Basu, A., Blavy, R. and M. Yulek. 2004. "Microfinance in Africa: Experiences and
Lessons from Selected African Countries. IMF Working Paper WP/04/174.

Boapeah, S. (2001). The Informal Economy in Kumasi. In: K. K. Adarkwah and J. Post (eds.). The Fate of the Tree: Planning and Managing in the Development of Kumasi, Ghana. Accra, Woeli Publishing Services, pp.59-77 
Buckley, R., and J. Kalarickal. 2004. "Shelter Strategies for the Urban Poor: Idiosyncratic and successful but hardly mysterious”. World Bank Policy Research Working Paper 3427, Washington, DC.

Charmes, J. (1990). A Critical Review of Concepts, Definitions and Studies in the Informal Sector. In Turnham, D.; B. Salome \& A. Schwarz (eds). The Informal sector revisited. Paris, France: OECD.

Charmes, J. (1996). Progress in Measurement of Informal Sector Employment. Regional Development Dialogue, Vol. 17, No. 1.

d'Cruz, C. and D. Satterthwaite. 2004. "Building Homes, Changing Official Approaches". International Institute for Environment and Development. Poverty Reduction Series, Working Paper 16.

Decardi-Nelson, I and Solomon-Ayeh, B. (2011). Towards Sustainable Housing Financing: Is Housing Mortgage an Option for Ghanaians? Journal of Building and Road.

Ferguson, B. (2003). "Housing Microfinance - A key to improving habitat and the sustainability of microfinance institutions". Small Enterprise Development. 14(1), $21-31$.

Grant, R. 2005. "Out of Place? Global Citizens in Local Spaces: A study of the informal settlements in Korle Lagoon evirons in Accra, Ghana.” Department of Geography and Regional Studies, University of Miami (unpublished).

Groves, R. 2004. "Challenges Facing the Provision of Affordable Housing in African Cities." Housing Finance International, XVII, 4, 26-31(June).

Haan, H. (1989). Urban Informal Sector Information: Need and Methods, Geneva, Switzerland: ILO.

ILO (2002). Decent Work and the Informal Economy. Paper presented at the goth Session, International Labour Conference, Geneva, Switzerland: ILO

ILO, (2002). Women and Men in the Informal Economy: A Statistical Picture. Geneva, Switzerland: ILO.

Lund, F. (1998). "Women Street Traders in Urban South Africa: A synthesis of selected Research Findings." CSDS Research Report, No.15, School of Development Studies, University of Natal, Durban, South Africa.

Merrill, S. and M. Tomlinson. (2006). "Housing Finance, Microfinance, and Informal Settlement Upgrading: An assessment of Ghana." Urban Institute for African Union for Housing Finance and USAID, (June). 
Merrill, S. and Tomlinson, M. (2006). "Housing Finance, Microfinance, and Informal Settlement Upgrading: An assessment of Tanzania," Urban Institute for USAID and African Union for Housing Finance.

Ninsin, K.A. (1991). The Informal Sector in Ghana's Political Economy. Freedom Publication, Accra.

Sethuraman, S.V. (1976). "The Urban Informal Sector: Concept, Measurement and Policy." International Labour Review, Vol.114.

Solomon-Ayeh, B. (2009). "The Spatial Dynamics of Street Trading in Ghana and Its Implications For Policy: A Case Study of Kumasi." PhD Dissertation submitted to the Department of Planning, Kwame Nkrumah University of Science and Technology, Kumasi (unpublished).

Tomlinson, M. R. (2007). “A Literature Review on Housing Finance Development In SubSaharan Africa." Commissioned by Finmark Trust.

Perry G. E., Maloney, W. F., Arias, O.S. Mason, A. D., Saavedra-Chanduri, J. and Fajnzylber, P. (2007). Informality: Exist and Exclusion. Washington, D.C: The World Bank. 